\title{
Unpacking Brazil's Leadership in the Global Biofuels Arena: Brazilian Ethanol Diplomacy in Africa
}

\author{
Stavros Afionis, Lindsay C. Stringer, Nicola Favretto \\ Julia Tomei, and Marcos S. Buckeridge*
}

\begin{abstract}
Biofuels represent an opportunity for Brazil to exert global leadership by substantially scaling up the production, consumption, and international trade of bioethanol. Africa represents an ideal venue in which to do this, given its suitable agro-climatic conditions and extensive land area. Brazil has consequently sought to establish bilateral partnerships with African countries, as well as North-South-South trilateral partnerships involving the EU and US. However, empirically grounded assessments of how Brazil's leadership aspirations have unfolded in practice through these partnerships are limited. In this article, we examine Brazil's potential to exert global political leadership, by analyzing its policybased, structural, and instrumental qualities in making bilateral and trilateral inroads regarding bioethanol production in Africa. Interviews in Brazil, Africa, and Europe suggest that both the bilateral and trilateral avenues have produced meager results. Lack of domestic strategy and vision, economic recession, and a fragmented alliance network have reduced Brazil's capacity to achieve its ethanol diplomacy objectives.
\end{abstract}

The rise of major emerging powers has elicited considerable debate, interest, and speculation in the field of global change. Brazil, India, and China are challenging the traditional dominance of the Global North, seeking to capitalize on their newly acquired strategic assets by undertaking political initiatives aimed at reforming global governance (Hopewell 2015). The formation of the trade and financial G20s indicates their growing presence in key decision-making fora like the World Trade Organization, while their deal-brokering role during the 2009

* This research was funded by the European Community's Seventh Framework Programme (FP7/ 2007-2013) under Grant Agreement No. 251132, by the Sustainability Research Institute (SRI) of the University of Leeds, and by the SUPERGEN Bioenergy Hub. Financial support was also received from the Instituto Nacional de Ciência e Tecnologia do Bioetanol-INCT do Bioetanol (FAPESP 2008/57908-6 and CNPq 574002/2008-1), and the Centro de Processos Biológicos e Industriais para Biocombustíveis-CeProBIO (FAPESP 2009/52840-7 and CNPq 490022/2009-0). This research was also supported by a Philip Leverhulme Prize (2013). We thank the anonymous reviewers, as well as Emily Brandão, George Holmes, Vivek Mathur, James Porter, Susanne Lorenz, and the SRI's Social and Political Dimensions of Sustainability (SPuDS) Research Group. 
Copenhagen climate conference signaled their emergence as pivotal actors in global environmental negotiations. Despite the proliferating literature on the implications of their growing status, empirical assessments of emerging powers' leadership strengths and weaknesses within specific issue areas remain scarce. Although studies have focused on their leadership potential, either individually or collectively, in relation to the climate change regime (Hochstetler and Viola 2012; Papa and Gleason 2012), similar investigations are largely lacking with respect to biofuels, which is a policy area in which Brazil is often portrayed as a global leader. However, empirically grounded assessments of Brazil's leadership are limited, a lacuna that this study aims to address.

Brazil has a long tradition in biofuels, based on the production of firstgeneration ethanol using sugarcane as feedstock. ${ }^{1}$ Consequently, over time, Brazil has developed substantial technological and scientific expertise for this specific crop and production technology, which it has explicitly sought to diffuse abroad through technical knowledge transfer, exchange of best practices, and privatesector investment, otherwise known as "ethanol diplomacy." For Brazilian policymakers, transforming the country into a world leader in bioenergy and creating a global biofuels market are central political objectives (Dalgaard 2012). The prerequisite for biofuels to develop into a globally traded commodity is a market with a constellation of countries not only consuming, but also producing, biofuels (Dalgaard 2012).

The African continent is vital to Brazil's ambitions. First, climatic parameters are important for the growth of energy crops. Sugarcane is a tropical crop, so sugarcane-based ethanol can only be produced in parts of Africa, Asia, and Latin America-that is, in countries located in tropical climatic zones similar to those of Brazil. Environmental similarities between the agro-climatic conditions in the African savannahs and the Brazilian cerrado therefore provide a familiar agro-ecological context, which has prompted Brazilian policy-makers to explore the replication of their sugarcane-ethanol model in Africa's savannahs (Amorim 2010). This idea was the driving force behind ethanol diplomacy in Africa during the administration of President Lula, whose prevailing view at the time was that African countries could meet part of their energy needs by imitating Brazil's experience, albeit at a lesser scale. ${ }^{2}$

Second, geographical factors are pertinent, because Africa is perceived as endowed with vast tracts of land into which to expand biofuel production (Dalgaard 2012; White 2013) - in contrast to, for example, Central American and Caribbean countries, whose limited land availability effectively rules out investments of more than 20,000 hectares. ${ }^{3}$ Finally, Brazil and Africa share affinities due to Brazil's close cultural, historical, and economic ties with a number of Lusophone African

1. Biofuels from food sources are collectively known as first-generation biofuels. Second-generation biofuels are produced from inedible sources, such as woody crops, energy grasses, or even agricultural and forestry residues, thereby avoiding competition with food production.

2. Interview \#54.

3. Interview \#25. 
countries, such as Mozambique, Angola, and Cape Verde. Indeed, business, language, and the African roots of Brazilian black culture are considered key forces behind Brazil's drive to deepen relations with the continent. ${ }^{4}$

Several benefits would ideally accrue from increased growth of the global biofuels market. For Brazil, it would provide a leadership opportunity linked to increased visibility, strategic positioning in an emerging global market, and expansion opportunities for its commercial sector. Africa is envisaged to benefit through reduced oil dependency and foreign debt, as well as stimulation of rural development and enhanced economic activities (Favretto et al. 2013). Except for South Africa, ethanol production in the African countries with the greatest potential for sugarcane cultivation exceeds domestic demands for blending, thereby creating export opportunities (Johnson and Batidzirai 2012).

This article applies a leadership theoretical framework, alongside empirical evidence, to evaluate Brazil's quest to exert global leadership within the biofuels arena, focusing specifically on its bilateral and trilateral partnerships involving African countries. It draws on secondary data from government documents, reports, and scientific studies, as well as on interviews with Brazilian, African, and EU stakeholders. Primary data were gathered through fifty-four semistructured interviews carried out across Brazil (March 2013, August-September 2014, and September 2015), EU headquarters (October 2013), and Africa (October 2013, July 2014, and May-June 2015) (see the Appendix for the full list). A purposive sample and snowballing approach were used to identify respondents.

\section{Insights from Theory on Leadership}

The literature on international cooperation emphasizes the decisive role of leadership for addressing transnational problems and forging global relationships. Capability, legitimacy, and credibility are considered imperative leadership prerequisites (Parker and Karlsson 2010), yet a range of (overlapping) categories for evaluating leadership have been developed in the literature (Grubb and Gupta 2000). Young (1991) identifies structural, entrepreneurial, and intellectual elements of leadership, while Underdal (1994) distinguishes between unilateral, coercive, and instrumental leaders. Malnes (1995) focuses on "threats and offers" leadership, problem-solving leadership, and directional leadership, while Andresen and Agrawala (2002) expand the analytical focus by considering intellectual, instrumental, power-based, and directional modes of leadership.

Each typology mentioned above was developed to address different regimes-for instance, climate change or disarmament negotiations. Consequently, each needs to be "adapted to the characteristics of the issues being negotiated" (Grubb and Gupta 2000, 19). Most typologies highlight capacityrelated aspects of leadership, the ability of actors to demonstrate the feasibility

4. Interview \#5. 
of alternative courses of actions, and their ability to effectively employ negotiation tactics, such as coalition-building. Here we utilize the typology of Papa and Gleason (2012), because it draws on all of the aforementioned frameworks, allowing for a better understanding of the leadership potential of Brazil in the area of global biofuels development. The following paragraphs further unpack the three dimensions of this typology: policy-based, structural, and instrumental leadership.

The first element of Papa and Gleason's typology is policy-based leadership: the ability of actors to "frame problems, promote particular policy solutions and implement them" $(2012,917)$. It amalgamates intellectual and directional modes of leadership, considering actors' abilities to provide vision and goals, as well as their determination to pioneer alternative policy solutions that demonstrate (through domestic implementation) feasibility, value, and superiority, thereby providing a model for others to emulate (Grubb and Gupta 2000; Underdal 1994). Such "demonstration effects," or leading by example (Karlsson et al. 2011, 92), constitute an important soft-power tactic that Brazil has been noted to use in the biofuels context (Afionis and Stringer 2014). Policy-based leadership for Brazil in this study therefore refers to its ability to instill the desirability of integrating biofuels into other actors' energy mixes. Disseminating vision internationally rests critically upon demonstrating vision domestically. Consequently, high policy-based leadership potential is not only reflected in past credentials; equally important, Brazil must demonstrate an ongoing commitment to a certain domestic policy solution that has worked or is working well.

The second element of the typology is structural leadership. This concerns an actor's capacity to take actions or deploy material and immaterial power resources that can incentivize, plus create costs and benefits, in a particular issue area (Karlsson et al. 2011). As Grubb and Gupta (2000) note, this type of leadership is a function of an actor's aggregate power-that is, its political strength in the global order, plus its weight with respect to the problem. The latter dimension is salient because power tends to be "issue-specific" and related to capability within a particular environmental policy domain. Altruism is not a prerequisite, but while the leader is seeking to satisfy its own objectives (Malnes 1995), it must also demonstrate consideration of others' concerns if durable joint initiatives are to emerge (Papa and Gleason 2012). In our study, high structural leadership potential depends on whether Brazil has the resources and will to deliver on its pledges to assist African nations with developing their biofuels markets in a socially, environmentally, and economically sustainable fashion.

Finally, instrumental leadership refers to the ability of an actor to use diplomatic skills to pursue issue linkages and to engineer winning coalitions (Papa and Gleason 2012). While coalition formation is important, maintaining and further developing these relationships is equally vital. Reliance upon integrative rather than distributive bargaining is imperative, for the leader needs to construct mutually beneficial solutions (Gupta and Ringius 2001). High instrumental 
leadership potential, hence, depends on the ability of an actor to deepen cooperation within the coalition and attract new allies (Papa and Gleason 2012). In this study, Brazil's ability to display instrumental leadership rests on whether it can successfully forge coalitions with other countries.

\section{Brazil's Ethanol Diplomacy in Africa}

Although Brazil's efforts to establish financial, political, and cultural relations in Africa date back to the 1960s, its prolonged economic rigidity did not allow tangible outcomes to be generated until recently. Capitalizing on a golden decade of economic growth coinciding with the beginning of the century, Brazil is now making a concerted effort to engage with Africa and enhance its own investment capacity and commercial presence, as well as its strategic and political weight. Such inroads have not passed unnoticed, with Brazil's increasing visibility as an international development actor being under close international scrutiny (Pierri 2013).

Two main narratives can be identified in the literature on Brazil's SouthSouth engagement. First is Brazil's official discourse, which stresses the unconditional nature of its development assistance (see ABC 2010; Banco Mundial e Ipea 2011). Underpinning the governmental rhetoric is an idealization of the way in which Brazil is acting in Africa, stressing solidarity, respect for the counterpart's sovereignty, and no development aid conditionality. Compatibility is often highlighted here-that is, that Brazil's own development experiences are similar to those of African countries, thus allowing the former to offer the latter tried and tested solutions (Cabral et al. 2013). Biofuels promotion in Africa is also underpinned by normative aspirations, with Brazil putting forward the potential of this energy source to spur development.

The second narrative offers a more negative perspective, viewing Brazil's attachment to Africa as a new form of colonialism. By advancing the interests of African and Brazilian entrepreneurs at the expense of, for example, African smallholders, Brazil's South-South cooperation is dismissed as yet another manifestation of the exploitation of poor nations by more affluent ones (Clements and Fernandes 2013; Thaler 2013). Adopting a softer approach, Lima (2005) emphasizes the instrumental role of South-South cooperation in maintaining and further advancing Brazil's own socioeconomic development via the promotion of its domestic capital in global markets. Regarding biofuels, when Brazil offers developmental support, commercial agents along the entire sugarcaneethanol supply chain are intentionally involved from the outset. This sets it apart from US and EU approaches, which rely on donor-led support and refrain from linking commercial activities with development aid (White 2013).

The Brazilian government has employed an array of tactics in promoting the production and use of biofuels in Africa. It has made extensive use of presidential diplomacy, especially during the term of President Lula (2003-2010), who visited twenty-nine African countries, signing agreements relating to biofuels along the way (Amorim 2010). The selection of countries was exploratory, 
with no coherent pattern; in almost all visits, Brazil would offer its help and, if the hosts expressed interest, a memorandum of understanding (MoU) would be signed. ${ }^{5}$ This explains why Brazil has agreements on biofuels with countries ranging from Egypt to South Africa, and from Liberia to Kenya. As of September 2015, ten of Brazil's fourteen cooperation agreements on biofuels or bioenergy with African countries, mostly in the western and southern sub-Saharan regions, had been concluded during President Lula's administration. ${ }^{6}$

Brazil has also increasingly entered into trilateral cooperation, involving African countries plus a Northern donor, with the intention of developing bioenergy projects. At the initiative of Brazil, tripartite undertakings involving the EU were agreed with Mozambique and Kenya (Afionis and Stringer 2014). Similarly, in 2007 an MoU on biofuels cooperation was signed between Brazil and the US, with a subset of the activities envisaged being directed toward stimulating private-sector biofuels investment in third countries. The initial focus was solely on Central American and Caribbean countries, but later it expanded to include African countries like Senegal and Guinea-Bissau (Dalgaard 2012).

\section{Brazil's Bilateral Path}

Despite the potential, bioenergy development in Africa is largely still in its infancy, due to limited capacity, food security concerns, and inadequate infrastructure. With a few exceptions (e.g., Malawi), African countries have only recently begun to introduce policies to leverage biofuel production. Policy development has largely focused on promulgating laws and regulatory mechanisms for compulsory minimum percentages of ethanol and biodiesel in national oil distribution circuits. Brazil is eager to further stimulate this trend, because legal clarity is a sine qua non prerequisite for attracting investments.

\section{Progress on the Ground: Brazilian Private-Sector Investments}

Brazil's private sector is behind several undertakings to enhance local refining capacities in Africa. In Malawi and Zimbabwe, Brazil's private sector has provided expertise for the construction of ethanol processing plants, ${ }^{7}$ while in Mozambique Brazilian companies Petrobras and Guaraní have acquired Cia de Sena, a local sugar production facility, and are exploring the viability of constructing a distillery. However, the investment required to modernize the mill is viewed as prohibitive, with Petrobras reportedly regretting buying "a piece of a museum." ${ }^{8}$

5. Interview \#54.

6. Bilateral agreements on agricultural cooperation with African countries follow a similar geographical as well as numerical pattern, with more than three-quarters of the twenty total agreements having been promulgated during President Lula's term. See http://dai-mre.serpro.gov.br/.

7. Interview \#23.

8. Interview \#41. 
In Sudan, Brazilian equipment and machinery were imported by local company Kenana, which, together with Brazilian firm Dedini, built a biofuels plant that has met with considerable success. Sudan has been portrayed as a model of sustainable biofuels production by Brazilian policy-makers, due to development of an infrastructure that is said to have led to job creation, enhanced food production, plus local and regional development. ${ }^{9}$

Finally, in Angola, Odebrecht teamed up with local companies, like Damer and Sonangol, to build several ethanol plants, ${ }^{10}$ the first of which initiated operations during 2014. ${ }^{11}$ In 2015, however, Odebrecht was convicted by a Brazilian labor court of holding Brazilian laborers, who had been illegally imported to Angola to work on the plant's construction, in conditions akin to slavery (Reuters 2015). Odebrecht announced it would appeal the decision on the grounds that the project was implemented by third-party contractors in accordance with both Angolan and Brazilian law. ${ }^{12}$

It is notable that Brazil has intentionally sought (through MoUs) to stimulate technology transfer and weave the private sector into its ethanol diplomacy processes. Dalgaard $(2012,196)$ notes that this "formula of publicprivate partnership" is central to Brazil's energy statecraft, given the influence and expertise of its agribusiness sector. While MoUs and other agreements are crucial to strengthening biofuel collaboration in terms of technical or policy implementation, actual technology transfers are largely executed by the private sector. Hence, visits to Brazil by developing country delegations regularly include a stopover in São Paulo for consultations with the region's highly influential sugarcane industry. ${ }^{13}$ However, when it comes to ethanol diplomacy, one cannot study it using bilateral agreements alone, since biofuel investments in Africa can also occur in the absence of official government-to-government arrangements. For example, Sudan is one of only two countries in Africa (the other being Angola) where concrete biofuel projects have been implemented so far (by Brazilian companies). However, when Dedini built Kenana's ethanol plant, Brazil and Sudan did not have an MoU in place.

\section{Brazilian Public-Sector Involvement}

Turning to the public sector, Brazil has aimed to attract private investment, mainly via conducting feasibility studies in African countries. Such studies are provided at no cost to the African governments that request them and review the prevailing environments for project development in biodiesel, ethanol, steam, electricity, and food production. African governments then decide whether or

\footnotetext{
9. Interview \#10.

10. Interview \#2.

11. Interview \#25.

12. Interview \#44.

13. Interview \#28.
} 
not to push forward with the recommended projects. ${ }^{14}$ This is a manifestation of Brazil's structural power capabilities, and is significant in terms of exerting instrumental leadership through coalition-building.

While eager to promote biofuels, Brazil is well aware of the bottlenecks posed by highly contentious international debates related to energy and food security, trade, and climate change mitigation (Afionis and Stringer 2014). Consequently, Brazil adapted its structural leadership with respect to the promotion of sugarcane-ethanol systems, conditioning the establishment of sugarcane plantations for ethanol production on the proviso that they go hand in hand with productivity gains in food crops, and that they only take place in countries endowed with sufficient arable land. ${ }^{15}$ Nevertheless, as the Senegalese case study discussed below illustrates, the ability of feasibility studies to assess the viability of producing biofuels in an environmentally, socially, and economically sustainable fashion has not escaped criticism.

Until recently, all feasibility studies in Africa had been conducted by the Getúlio Vargas Foundation (Fundação Getúlio Vargas-FGV) ${ }^{16}$ and were meant to serve as tools for attracting international investment attention to the recommended projects. However, in 2013 a lack of tangible results prompted the Brazilian government, through the Brazilian Development Bank (BNDES), to try a "fresh approach," by hiring US consulting firm Bain \& Company to conduct feasibility studies in the eight-nation Economic and Monetary Union of West Africa (UEMOA). Bain's final recommendations were for the UEMOA countries to replicate the Brazilian model, investing in sugar production first, followed by the production of electricity and ethanol. ${ }^{17}$

To date, feasibility studies have identified Tanzania, Senegal, Zambia, and Mozambique as the most promising locales for biofuels. ${ }^{18}$ However, progress has been slow, and none of the feasibility studies have led to actual project commencement. Mozambique has attracted Brazil's utmost attention, given the common language, favorable climate, low population density, and its perceived land availability. While Mozambique's 2009 biofuels strategy articulated a blending mandate of inter alia 10 percent for ethanol by 2015, field research revealed that, at present, there is no blending of biofuels with petrol or diesel, and production of biofuels is negligible. Indeed, of the thirty-seven biofuelrelated projects that had applied for licenses between 2008 and 2014, only five were operational, and all remained in the pilot phase. ${ }^{19}$ The failure of these early biofuels projects is likely to have impacted negatively on the government's resolve to promote biofuels, while the recent discovery of massive fossil fuel

14. Interview \#14.

15. Interview \#25.

16. FGV is a higher education institution with a strong consultancy profile.

17. Interview \#26.

18. Interview \#14.

19. Interview \#42. 
reserves off its coast was perceived to have further dampened enthusiasm for biofuels. $^{20}$

While Mozambique-based Brazilian interviewees expressed their confidence that the country would eventually develop biofuels, such optimism was not shared by Mozambique's sugar sector. They cited the lack of (domestic) markets, a competitive investment climate, and legislation as barriers to biofuel investment. ${ }^{21}$ Even so, Brazil has made a concerted effort to assist Mozambique with developing its own biofuels program and market, with MoUs on biofuels development and renewable energy being signed in 2007 and 2015, respectively. Despite the centrality of Mozambique to Brazil's ethanol diplomacy vision, government-to-government technical knowledge transfer has been rather limited. Although Brazil offered its help to the Mozambicans, the latter never really took bilateral cooperation to the next level. According to the Mozambican Ministry of Energy, the $2007 \mathrm{MoU}$ mainly focused on the exchange of ideas and on shaping policies, which had included study tours to visit ethanol-related institutions and companies in Brazil. ${ }^{22}$

Mozambicans justified their disinclination to proceed further in terms of skepticism as to whether the different social, political, and environmental contexts allowed for Brazil's experience to be directly replicated in Mozambique. ${ }^{23}$ For instance, food security concerns were central, prompting Mozambique to seek the assistance of the Dutch in developing its biofuels sustainability framework (see NL Agency 2014). For Brazil, this lack of technical interactions was a disappointing turn of events, with concerns being raised that in the absence of adequate infrastructure and laboratories, the Mozambican standards were "too rigid for [the country's] level of development." ${ }^{24}$ However, Brazil's advice has been sought on some issues, such as whether to have a minimum-price policy for ethanol or to attach ethanol remuneration from gasoline in the international market as a parameter. Mozambique's draft pricing structure was also sent to the Brazilian government for review. ${ }^{25}$

\section{Brazil's Trilateral Path}

In addition to bilateral arrangements, Brazil has augmented its instrumental leadership by developing trilateral cooperation arrangements, whereby it provides assistance alongside a Northern codonor to a beneficiary country. Building coalition networks with prominent actors in the biofuels arena serves instrumental purposes if Brazil is to achieve its goal of commoditizing ethanol. Under the 2007 MoU with the US, feasibility studies were carried out by FGV in

20. Interviews \#34, 40, and 48.

21. Interviews \#40 and 41 .

22. Interview \#37.

23. Interviews \#36 and 37.

24. Interview \#41.

25. Interview \#37. 
Guinea-Bissau and Senegal. While the former was never officially presented, because soon after its completion the country experienced a coup, the latter proceeded as planned and outlined the advantages of projects for sugarcane, cottonseed oil, sunflower, and soybean oil. Ethanol from sugarcane and biodiesel from cotton attracted the attention of Senegalese policy-makers, with further project development awaiting governmental approval of the regulatory framework. ${ }^{26}$

A note of caution is warranted, however, as a review by the UN Environment Programme (UNEP) of FGV's 2010 Senegalese feasibility study raised concerns about whether all pillars of sustainable development had been assessed equally. In addition to concerns that the study adopted a desk study approach with a two-week field trip, UNEP's review also questioned the rationale behind some of the proposed projects. For instance, although enhancing sugarcane production in one region of Senegal was highlighted as feasible, the region faces severe water shortages that might otherwise have led to it being declared unfit for production. ${ }^{27}$ UNEP concluded that while the FGV study served as "a great tool" for the private sector to identify investment opportunities, it was less well designed to support policy-makers in devising adequately sustainable strategies and policies. ${ }^{28}$

Turning to the EU, the current legal and political framework for bilateral relations with Brazil is the strategic partnership agreement, established in 2007 at the initiative of the EU Portuguese presidency. Under the auspices of this interregional collaborative undertaking, during the third EU-Brazil Summit in Stockholm in 2009, it was decided to set up joint trilateral projects for bioenergy and ethanol production in Africa, with Kenya and Mozambique as pilot countries. Brazil would lead on the Mozambican project, and the EU on Kenya. The selection of these two countries was based on technical and political factors. Starting with the former factor, Brazil was in favor of countries with soil and climatic conditions favorable to large-scale sugarcane cultivation-that is, the crop with which it has transferable expertise. Turning to the latter, the main criterion was domestic political stability, since both countries had secure democratic governments that the EU and Brazil "could trust." ${ }^{29}$

The agreements to initiate these trilateral cooperative endeavors between Africa, the EU, and Brazil have been reported in the literature, but so far no evaluation has been undertaken of how they have translated into practice. For instance, Franco et al. (2010) note that high EU tariffs on Brazilian ethanol imports have partly stimulated the joint EU-Brazil decision to establish production in third countries, and thus to engage in biofuels and bioelectricity projects in Mozambique. Bypassing the debate on tariffs and securing preferential

26. Interviews \#10, 28, 29, 33, and 51.

27. Interview \#53.

28. Interview \#53.

29. Interview \#54. 
access to EU markets has been also cited by Amanor (2013) as the raison d'être behind these trilateral endeavors. Thaler $(2013,151)$ further highlights Brazil's "heavy dose of self-interest" in the decision to table plans for trilateral cooperation with the EU. The above debate is consistent with observations that altruism is not a prerequisite for exerting leadership (Malnes 1995). Our interviews with relevant stakeholders, nevertheless, demonstrate that trilateral cooperation in both Kenya and Mozambique failed to progress beyond wishful thinking.

In the case of Kenya, initial discussions took place between the Brazilian embassy and the EU delegation to Kenya in 2010. These indicated a divergence in terms of the desired policy outcomes from the project. While both actors stressed the need to assist Kenya in promulgating a regulatory framework that would provide for sustainable policies, the EU was skeptical of Brazil's drive for market expansion and creation of investment opportunities in the country. ${ }^{30}$ The EU also lacked an institutional mechanism for cofinancing trilateral cooperative undertakings in Kenya that involved private-sector investments in biofuels. One interviewee indicated that at the summitry level, focus had been on the political and strategic benefits of cooperation, with the implementation aspect having being overlooked. ${ }^{31}$ Parallel cofinancing, whereby actions are broken down into clearly identifiable subactions, each funded by a different cofinancing partner, was eventually pinpointed as a solution.

In 2011, the EU Kenyan delegation decided to proceed by proposing to DG DEVCO (the Directorate-General for Development and Cooperation) a scoping study to identify relevant initiatives that had already been implemented in Kenya, what regulations were already in place, and the kind of external support the country would require. At this point, the process halted. ${ }^{32}$ With the tide turning increasingly against biofuels as a sustainably sound energy option, the trilateral undertaking in Kenya fell out of favor with EU headquarters in Brussels, which ceased considering this project a priority and repeatedly delayed authorizing the EU delegation in Kenya to proceed. When the Brazilian embassy in Kenya enquired about the state of progress, it was suggested that their headquarters speak directly with Brussels, which resulted in an inconclusive reply of "we are looking into it." ${ }^{\text {"33 }}$ As of July 2015, no further action has been undertaken, indicating unwillingness on the part of the EU to be further associated with this project.

Turning to Mozambique, the local EU delegation and the Brazilian embassy initially discussed the terms of reference for a Brazilian-led study that would analyze biofuels production in the country and serve as a prefeasibility study for potential investments. The EU stressed the need to take into account land grabbing and food security concerns, alongside the involvement of local farmers

30. Interviews \#9 and 22 .

31. Interview \#22.

32. Interview \#22.

33. Interview \#18 
in the production of feedstock, plus Mozambican small- and medium-sized enterprises in the processing part of the value chain. ${ }^{34}$ As with Kenya, the EU delegation highlighted a lack of specific financial instruments to partner with the Brazilians to cofinance trilateral undertakings in Mozambique.

Discussions, however, did not progress further, because the EU was informed that the Brazilian company Vale would provide the funds for the FGV to carry out the feasibility study. ${ }^{35}$ For the EU, this represented a potential conflict of interest, as Vale's portfolio included biofuels and the company had already expressed interest in diversifying its operations into Africa. Consequently, complications could not be ruled out, especially since private and public funds were combined through the same channel to finance activities aimed in principle at advancing Mozambican public wellbeing. ${ }^{36}$ Brazil's retort was that apart from ownership of the report remaining with its government, the sheer costs involved in undertaking the study ( $\approx$ US $\$ 1$ million) necessitated private-sector involvement. ${ }^{37}$ Eventually, Brazil proceeded alone (with Vale input) to produce the feasibility study, and currently it is analyzing what private-sector actors could be involved in its operationalization. The EU received a copy of the final feasibility study but was not requested to formally comment. Consequently, the EU is not officially associated with this output. ${ }^{38}$

\section{Implementation Barriers}

Unlike in Brazil's ethanol diplomacy endeavors in Latin America, the low level of agricultural technology, lack of infrastructure, and political instability were cited as prime complications for scaling up biofuels production in Africa. ${ }^{39}$ In most African countries the level of agricultural development is relatively poor and based predominantly on complex and contested customary land rights, as well as on smallholders that frequently switch crops and are not organized in cooperatives. ${ }^{40}$ Lack of capital, infrastructure, skilled labor, and legal and regulatory frameworks further drive market and investor uncertainty. ${ }^{41}$ Limited local research and development is also important, given that the local varieties of sugarcane differ from those in Brazil. ${ }^{42}$

Unstable political conditions greatly hinder investments, as Brazilian funding institutions, like BNDES, face difficulties covering the requirements and mitigation costs linked to dynamics such as currency fluctuations. ${ }^{43}$ Civil

34. Interview \#21.

35. Interview \#21.

36. Interview \#21.

37. Interview \#18.

38. Interviews \#21, 35, and 40.

39. Interview \#45.

40. Interview \#46.

41. Interview \#39.

42. Interview \#15.

43. Interview \#4. 
wars, like that in Guinea-Bissau, are also a deterrent to investors. A Brazilian delegation visited Mali in 2012 to discuss biofuels cooperation, only to hastily evacuate the country due to insurgency in the north. ${ }^{44}$ Unforeseen events were also highlighted, with Bain, for instance, postponing plans to present its study findings to the UEMOA country governments during the summer of 2014 due to the Ebola virus epidemic. ${ }^{45}$ However, one of the most important barriers relates to the heated debate over biofuels' sustainability that ignited in the late 2000s and led many African governments to shift away from biofuels. ${ }^{46}$ The unexpected slump in oil prices of more than 50 percent since mid-2014, the longest-running decline for 20 years, even further deterred many African countries from considering biofuel investments in the near term.

\section{Discussion}

\section{Policy-Based Leadership}

Having outlined Brazil's bilateral and trilateral undertakings in Africa, in this section we link back to the theoretical framework, to assess the extent to which Brazil has been able to exert leadership in promoting biofuels abroad. Brazil has clearly demonstrated policy-based leadership, by unilaterally setting an example through the implementation of the world's largest and most sophisticated biomass-to-energy program. During the 2000s, Brazil was effectively the poster child of ethanol fuel, but due to a combination of factors discussed below, the Brazilian sugarcane sector has recently plunged into crisis. Consequently, even Brazil has experienced a dampening of enthusiasm for biofuels, and this has led to challenges in promoting its vision and direction.

First, dry climatic conditions, coupled with poor plantation management and planning decisions, effectively crippled ethanol production in Brazil during the early 2010s, fueling market uncertainty, driving ethanol prices up, and forcing the importation of ethanol from the US in 2011 (Angelo 2012). Second, international and domestic economic developments have affected Brazilian biofuel production. The global economic crisis emerged when the Brazilian sugarcane sector was export-oriented and engaging in new investments to grow its way out of deep debt. The turmoil that ensued effectively halted domestic ethanol production expansion plans, with the sector resorting to harvesting cane from older, less productive sites instead of developing new plantations (Angelo 2012). Reduced average yields were exacerbated by the unfavorable climatic conditions, culminating in an ethanol supply crisis that left the sector in disarray.

Domestic politics were not conducive, either, with President Rousseff's policies being blamed as a main culprit for the prolonged period of upheaval

44. Interview \#29.

45. Interview \#28.

46. Interview \#54 
that plagued the sugarcane sector. Brazilian interviewees argued that biofuels are not a priority policy area for Rousseff's administration, which accords far greater attention to the oilfields that were discovered off the Brazilian coast during the late 2000s. ${ }^{47}$ Indicative of the reduced priority assigned to biofuels is the rapidity with which they have been subjugated in order to tackle more pressing and immediate concerns. In particular, President Rousseff's decisions to control inflation by capping petrol and diesel prices, and by cutting taxes on petrol but not ethanol, spelled a major competitive setback for the ethanol sector. ${ }^{48}$ Precipitously low international sugar prices further complicated the situation, with 10 percent of the Brazilian sugarcane sector suspending its operations during the 2014 growing season to safeguard against losses. ${ }^{49}$

A lack of domestic strategy and vision has resulted in the future direction of ethanol as an energy option in Brazil being increasingly debated ${ }^{50}$ While several interviewees expected little policy change following President Rousseff's reelection for a second term in October 2014, she subsequently took action that was received positively by the sugarcane-ethanol sector. Ranking highest in importance was the decision to increase significantly the taxes on fossil fuels, as well as the communication of Brazil's ambitious climate change pledge for 2030 ahead of the December 2015 Paris summit. ${ }^{51}$ Interviewees, however, were quick to downplay the extent to which these developments should be perceived as indicative of steps toward (re)assuming a policy-based leadership position. Increases in fossil fuel taxes were unanimously seen as a revenue-raising device to reduce the country's budget deficit, while the pledge to increase the share of sustainable biofuels in the Brazilian energy mix to approximately 18 percent by 2030 was largely expected, as Brazil needed "to have something to show." 52 Concrete steps toward implementation of the pledge will probably be undertaken by future administrations. President Rousseff's overriding near-term priority will be to continue in power and avoid impeachment over allegations that she disguised a widening fiscal deficit as she campaigned for reelection. ${ }^{53}$

Inevitably, Brazil's ethanol diplomacy has been impacted by this domestic standstill. While some interviewees noted that ethanol diplomacy has now retracted into a lower-priority issue, others argued that it had gradually died off in the aftermath of President Rousseff's ascendance to power. She was regularly portrayed as a fossil-fuel-oriented person with strong ties to the oil industry, disinclined to follow in President Lula's footsteps when it came to promoting ethanol abroad. For instance, Casa Civil's ${ }^{54}$ staff dedicated to ethanol

47. Interviews \#24, 27, 29, 30, 31, 49, and 54 .

48. Interview \#27.

49. Interview \#27.

50. Interviews \#13, 24, 27, 29, and 30.

51. Interviews \#47, 48, and 49.

52. Interviews \#43, 46, 48, and 49.

53. Interviews \#44 and 49.

54. The Executive Office of the President of Brazil. 
diplomacy affairs under the Lula administration were reassigned to other duties, ${ }^{55}$ with ethanol diplomacy left in the hands of ministry-level bureaucrats who have attempted to keep it afloat in the absence of positive presidential leadership, vision, and coordination. ${ }^{56}$ In terms of policy-based leadership, Brazil has not been sending positive signals to the countries where it wants to promote biofuels, leading to messages that can be problematic and confusing. Brazil's struggle to conceptualize its domestic vision with respect to biofuels has caused suspicion among some African partners, ${ }^{57}$ and if this remains unchecked, it could taint Brazil's credibility as a global biofuel leader. Following that, a reconceptualization of Brazil's international vision might also be warranted, as indicated by our Mozambican case study findings.

\section{Structural Leadership}

Even though its political strength in the global order is only a fraction of, for example, China's, Brazil still has the resources and scientific expertise required to successfully pursue biofuels abroad. This was especially true for Lula's administration, which supported key ethanol diplomacy actors-for instance, the Brazilian Cooperation Agency-with sizable budgetary increases. ${ }^{58}$ As one interviewee noted, "if you needed to go to Africa, Europe or Asia two times a month, he would give you the money to do it." ${ }^{59}$ However, a note of caution is necessary here. Despite the allocation of significant resources, the leadership task at hand was viewed by Brazil's policy circles at the time as greatly exceeding the country's human and financial structural capabilities. Complaints were often voiced in ministries that "every time Lula comes back, we have another MoU." ${ }^{\prime 60}$ Additionally, handling an ever-increasing influx of foreign delegations made heavy demands on the available resources: "We received five or six delegations a month. It was too much, we were overwhelmed. Our staff on renewables ... was only about six people." ${ }^{\prime \prime 1}$

Under the Rousseff administration, Brazil's economic outlook has darkened considerably, with inter alia falling domestic demand, high inflation, and deteriorating investor confidence having pushed the country to the brink of recession. ${ }^{62}$ Consequently, Brazil's aid budget has been massively reduced, such that technical cooperation assistance requests from (particularly) African countries have been declined. ${ }^{63}$ The Ministry of Agriculture's overall budget

55. Interview \#54.

56. Interviews \#24, 26, 27, 28, 29, and 30.

57. Interview \#27.

58. Interviews \#50 and 54.

59. Interview \#48.

60. Anonymous interview.

61. Interview \#48.

62. The Economist, December 1, 2015.

63. Interviews \#50 and 54. 
for cooperation has been more than halved, constraining its ability to pursue projects on biofuels in Brazil that could potentially be extended to Africa. ${ }^{64}$ Another interviewee noted that nowadays they simply respond to requests for assistance, whereas in the past they had been far more proactive. ${ }^{65}$

Budgetary constraints have also impacted capacity-building and dissemination activities, primarily toward African and Latin American countries. In 2008 the Brazilian Agricultural Research Cooperation (Embrapa) set up permanent offices in Accra, Ghana, to tackle in a more systematic manner the continuous flow of requests from African countries interested in Brazil's technical expertise in tropical agriculture. However, this bureau is underfunded and understaffed, prompting one interviewee to dismiss it as a public relations exercise. ${ }^{66}$ Furthermore, the hosting of the 2013 Bioenergy Week in Brasilia was only possible because it was organized under the auspices of the Global Bioenergy Partnership (GBEP) and sponsored by, inter alia, the US and the Organization of American States. ${ }^{67}$ Similar events, such as the São Paulo Ethanol Weeks of 2008 and 2009, had been financed primarily by the Brazilian government, but were subsequently discontinued due to budgetary issues. ${ }^{68}$ Consequently, ministries eager to spearhead such events need to "diversify and be creative" to secure funding, relying on partnerships with international initiatives like GBEP, intergovernmental organizations, and private-sector actors. ${ }^{69}$

A final point regarding structural leadership concerns Brazil's sugarcane industry sector, a key (financial) government ally when it comes to ethanol diplomacy. Although bilateral cooperation is supported by government diplomacy, it is implemented by the private sector. Successful ethanol diplomacy therefore presupposes a healthy sugarcane industry. However, domestic constraints mean that for the past few years the industry has been operating at a loss. Current conditions thereby largely rule out pursuing investment opportunities abroad. ${ }^{70}$ Overall, Brazil is drawing heavily on its past track record with regard to its structural leadership credentials, which remain threatened by funding cuts and an ailing private sector.

\section{Instrumental Leadership}

In closing, Brazil's record of instrumental leadership has been mixed, characterized by the dynamics of its coalition network. Several highly ambitious projects have floundered, with those in Ghana and Tanzania serving as examples. In the former, although plans by Odebrecht in 2010 to build an ethanol plant 
had secured financial approval by BNDES, the project was not implemented when one of its Ghanaian partners went bankrupt. ${ }^{71}$ Tanzania had been earmarked by Brazilian policy-makers as possessing great potential for biofuels production. ${ }^{72}$ Following requests for assistance, Brazil initiated an FGV-led feasibility study in the Rufiji valley. In addition, Petrobras was to carry out a viability study for blending, with an MoU to this effect signed during President Lula's visit to Tanzania in 2010. The FGV study remained at draft stage, while the Petrobras one was completed-indicating potential for up to 9-percent blends-but preliminary tests were never carried out. The stalemate was largely attributed to a loss of interest on the part of Tanzania's government, due to the concurrent discovery of vast offshore natural gas deposits. ${ }^{73}$

Setbacks aside, Brazil's direct presence in Africa is currently limited to a handful of countries (Mozambique, Angola, and Sudan), while a few others, like Zimbabwe and Malawi, have accessed Brazil's expertise in the construction of ethanol-processing plants. The overall results have been meager at best, with Mozambique, Brazil's flagship ethanol diplomacy endeavor, serving as an illustrative example. In addition, FGV's feasibility studies have not yet led to concrete results, and the same is true for many MoUs signed with various African countries. Only 10-20 percent of the more than seventy MoUs negotiated by Brazil with countries worldwide have actually led to active cooperation. ${ }^{74}$

While engagement with Africa to date may not have lived up to expectations, recent years have seen some renewed effort on the part of Brazil to stimulate ethanol diplomacy undertakings, as evidenced, for example, by the 2013 BNDES decision to invest in Bain's feasibility studies in West Africa. Moving from a national to a regional focus was seen as a way of taking things forward, with the partnership with GBEP envisaged as another tool in facilitating this transition. The 2013 Bioenergy Week in Brasilia, as well as its sequel in Maputo, Mozambique, in May 2014, allowed Brazil to network with Latin American and African countries. ${ }^{75}$ In May 2015, Brazil again relied on its partnership with GBEP to organize a similar event in Asia, held in Medan, Indonesia.

Turning to trilateral cooperation, while Brazil has put in place an expansive alliance with the US, it has struggled to form a lasting and viable coalition with the EU due to the latter's sustainability concerns. Although we do not dismiss the basic values (e.g., environmental) underlying the EU's approach toward biofuels, an interest-based perspective could help provide a more complete understanding of how an actor's preferences concerning international environmental cooperation are shaped. In this regard, our research suggests that the EU was skeptical about being part of projects that would benefit Brazil's longterm commercial interests. The objective of the EU was not to finance business 
opportunities for $\mathrm{Brazil}^{76}$ or to contribute to the development of an international biofuels market under Brazil's leadership. ${ }^{77}$ While the EU welcomed any Brazilian biofuel-related activities that could realize sustainable benefits for African people, it was not inclined to fund them. As one EU official explained, "Brazil will go on and search for other partners, but the EU is not getting on this train." ${ }^{178}$

An important finding emerging from our study concerns the perceived difficulty faced by Brazilian policy-makers when trying to interact and cooperate with their EU counterparts. In trilateral cooperation endeavors, the expressed feeling was that "we talk, we talk, but we don't go for concrete actions."79 Brazilian policy-makers in Brussels argued that DG DEVCO, which is the provider of funds for development cooperation, blocked biofuel undertakings in Africa on sustainability grounds. ${ }^{80}$ This was nevertheless deemed confusing, since other DGs were engaged in biofuel cooperation with Brazil on other fronts. ${ }^{81}$ Interviewees drew parallels with the trilateral biofuel undertakings in Africa, Central America, and the Caribbean that involved the US as a codonor. The view was that the US "is more proactive, we see a clear intention to go to the next step: implementation." ${ }^{82}$ Consequently, various projects and dissemination activities are taking place in the aforementioned regions, albeit not at great scale. $^{83}$

\section{Conclusions}

In this article we examined Brazil's potential to exert leadership through its bilateral and trilateral efforts to promote biofuels in Africa. Apart from the notable exceptions of Angola and Sudan, the bilateral avenue has barely moved beyond political deliberations and feasibility studies, while the trilateral approach involving the EU has struggled to get off the ground. In terms of Brazil's leadership potential, an evaluation of Brazil's bilateral and trilateral undertakings in Africa demonstrated that in terms of policy-based leadership, a lack of vision and direction is apparent. Regarding structural power, Brazil has the material and scientific resources required, but the domestic situation and budget constraints have limited the abilities of public- and private-sector

76. Interview \#21.

77. Interview \#22.

78. Interview \#8.

79. Interview \#14; see also \#1.

80. Interview \#18.

81. Interviews \#15 and 20.

82. Interview \#14.

83. Interviews \#15 and 20. These activities have predominantly involved workshops and other technical knowledge transfer initiatives. Some concrete projects have also been implemented. For example, under the US-Brazil MoU, El Salvador has received state-of-the-art technology to reinforce its ethanol production capacity, and Honduras inaugurated the country's first ethanol pilot plant in July 2014 with the assistance of Brazil, the US, and OAS. 
actors to engage in biofuel activities abroad. Finally, in terms of instrumental leadership, while Brazil has had successes in terms of coalition-building, the EU's disinclination to participate in trilateral biofuel undertakings constrains the reach of Brazil's ethanol diplomacy discourses.

Brazil's attempt to exert global leadership has been compromised by the significant change in the international perception of biofuels and the dynamics of the global political economy. Although Brazil can do little to alter this, the perplexing domestic biofuel policy situation does not send appropriate signals to potential partner countries. For Brazil to achieve its global leadership goal in the biofuels arena, a vital first step will be the reconsolidation of a domestic vision. Doing so will enable Brazil to take advantage of technological innovations in advanced biofuels that could change the tide with respect to biofuels in the international scene. ${ }^{84}$

\section{References}

ABC. 2010. A cooperação técnica do Brasil para a África. Available from www.abc.gov.br/ imprensa/mostrarnoticia/370, accessed December 2015.

Afionis, Stavros, and Lindsay C. Stringer. 2014. The Environment as a Strategic Priority in the European Union-Brazil Partnership: Is the EU Behaving as a Normative Power or Soft Imperialist? International Environmental Agreements: Politics, Law and Economics 14 (1): 47-64.

Amanor, Kojo Sebastian. 2013. Expanding Agri-Business: China and Brazil in Ghanaian Agriculture. IDS Bulletin 44 (4): 80-90.

Amorim, Celso. 2010. Brazilian Foreign Policy Under President Lula (2003-2010): An Overview. Revista Brasileira de Política Internacional 53: 214-240.

Andresen, Steinar, and Shardul Agrawala. 2002. Leaders, Pushers and Laggards in the Making of the Climate Regime. Global Environmental Change 12: 41-51.

Angelo, Claudio. 2012. Growth of Ethanol Fuel Stalls in Brazil. Nature 491: 646-647.

Banco Mundial and IPEA. 2011. Ponte sobre o Atlântico Brasil e África Subsaariana: parceria Sul-Sul para o crescimento. Available from www.ipea.gov.br/portal/ index.php? option $=$ com_content $\&$ view $=$ article $\& i d=12637$, accessed December 2015.

Cabral, Lídia, Alex Shankland, Arilson Favareto, and Alcides Costa Vaz. 2013. BrazilAfrica Agricultural Cooperation Encounters: Drivers, Narratives and Imaginaries of Africa and Development. IDS Bulletin 44: 53-68.

Clements, Elizabeth, and Bernardo Mançano Fernandes. 2013. Land Grabbing, Agribusiness and the Peasantry in Brazil and Mozambique. Agrarian South: Journal of Political Economy 2 (1): 41-69.

Dalgaard, Klaus Guimarães. 2012. The Energy Statecraft of Brazil: Promoting Biofuels as an Instrument of Brazilian Foreign Policy, 2003-2010. PhD Thesis, Department of International Relations, London School of Economics. 
Favretto, Nicola, Lindsay C. Stringer and Andy Dougill. 2013. Unpacking Livelihood Challenges and Opportunities in Energy Crop Cultivation: Perspectives on Jatropha curcas Projects in Mali. Geographical Journal 180 (4): 365-376.

Franco, Jennifer, Les Levidow, David Fig, Lucia Goldfarb, Mireille Hönicke, and Maria Luisa Mendonça. 2010. Assumptions in the European Union Biofuels Policy: Frictions with Experiences in Germany, Brazil and Mozambique. Journal of Peasant Studies 37 (4): 661-698.

Grubb, Michael, and Joyeeta Gupta. 2000. Leadership: Theory and Methodology. In Climate Change and European Leadership: A Sustainable Role for Europe?, edited by Michael Grubb and Joyeeta Gupta, 15-24. Dordrecht, The Netherlands: Kluwer.

Gupta, Joyeeta, and Lasse Ringius. 2001. The EU's Climate Leadership: Reconciling Ambition and Reality. International Environmental Agreements: Politics, Law and Economics 1 (2): 281-299.

Hochstetler, Kathryn, and Eduardo Viola. 2012. Brazil and the Politics of Climate Change: Beyond the Global Commons. Environmental Politics 21 (5): 753-771.

Hopewell, Kristen. 2015. Different Paths to Power: The Rise of Brazil, India and China at the World Trade Organization. Review of International Political Economy 22 (2): 311-338.

Johnson, Francis X., and Bothwell Batidzirai. 2012. Renewable Resources from Sugar Cane: The Energy, Environment and Development Context for Africa. In Bioenergy for Sustainable Development and International Competitiveness, edited by Francis X. Johnson and Vikram Seebaluck, 1-15. London, UK: Routledge.

Karlsson, Christer, Charles Parker, Mattias Hjerpe, and Björn-Ola Linnér. 2011. Looking for Leaders: Perceptions of Climate Change Leadership Among Climate Change Negotiation Participants. Global Environmental Politics 11 (1): 89-107.

Lima, Maria Regina Soares. 2005. A política externa brasileira e os desafios da cooperação Sul-Sul. Revista Brasileira de Política Internacional 48: 24-59.

Malnes, Raino. 1995. "Leader" and "Entrepreneur" in International Negotiations: A Conceptual Analysis. European Journal of International Relations 1 (1): 87-112.

NL Agency. 2014. Mozambique Biofuel Sustainability Framework. Available at http:// english.rvo.nl/sites/default/files/2014/03/Mozambique\%20Biofuel\%20Sustainability\% 20Framework_0.pdf, accessed October 2015.

Papa, Michaela, and Nancy W. Gleason. 2012. Major Emerging Powers in Sustainable Development Diplomacy: Assessing Their Leadership Potential. Global Environmental Change 22: 915-924.

Parker, Charles F., and Christer Karlsson. 2010. Climate Change and the European Union's Leadership Moment: Ah Inconvenient Truth? Journal of Common Market Studies 48 (4): 923-943.

Pierri, Francesco M. 2013. How Brazil's Agrarian Dynamics Shape Development Cooperation in Africa. IDS Bulletin 44 (4): 69-79.

Reuters. 2015. Brazil Convicts Odebrecht Group for Slavery-Like Practices in Angola. Available at www.reuters.com/article/2015/09/02/brazil-odebrecht-slaveryidUSL1N11802U20150902, accessed December 2015.

Thaler, Kai. 2013. Brazil, Biofuels and Food Security in Mozambique. In Agricultural Development and Food Security in Africa, edited by Fantu Cheru and Renu Modi, 145-158. London: Zed Books. 
Underdal, Arild. 1994. Leadership Theory: Rediscovering the Arts of Management. In International Multilateral Negotiation: Approaches to the Management of Complexity, edited by William Zartman, 178-179. San Francisco, CA: Jossey-Bass.

White, Lyal. 2013. Emerging Powers in Africa: Is Brazil Any Different? South African Journal of International Affairs 20 (1): 117-136.

Young, Oran R. 1991. Political Leadership and Regime Formation: On the Development of Institutions in International Society. International Organization 45 (3): 281-308. 


\section{Appendix (List of interviews)}

\begin{tabular}{|c|c|c|c|c|}
\hline No. & Date & City & Mode & Actor \\
\hline 1 & October 2011 & Brussels & $\mathrm{FtF}^{*}$ & $\begin{array}{l}\text { Brazilian Delegation } \\
\text { to the EU }\end{array}$ \\
\hline 2 & February 2013 & São Paulo & $\mathrm{FtF}$ & University of São Paulo \\
\hline 3 & February 2013 & São Paulo & $\mathrm{FtF}$ & University of São Paulo \\
\hline 4 & February 2013 & Rio de Janeiro & $\mathrm{FtF}$ & BNDES \\
\hline 5 & February 2013 & Rio de Janeiro & $\mathrm{FtF}$ & CENPES/Petrobras \\
\hline 6 & February 2013 & Rio de Janeiro & $\mathrm{FtF}$ & CENPES/Petrobras \\
\hline 7 & March 2013 & Rio de Janeiro & $\mathrm{FtF}$ & $\begin{array}{l}\text { Petrobras } \\
\text { Biocombustível }\end{array}$ \\
\hline 8 & March 2013 & Brasilia & $\mathrm{FtF}$ & $\begin{array}{l}\text { EU Delegation } \\
\text { to Brazil }\end{array}$ \\
\hline 9 & March 2013 & Brasilia & $\mathrm{FtF}$ & $\begin{array}{l}\text { EU Delegation } \\
\text { to Brazil }\end{array}$ \\
\hline 10 & March 2013 & Brasilia & $\mathrm{FtF}$ & $\begin{array}{l}\text { Brazilian Ministry of } \\
\text { External Relations }\end{array}$ \\
\hline 11 & March 2013 & Brasilia & $\mathrm{FtF}$ & $\begin{array}{l}\text { Brazilian Ministry of } \\
\text { Environment }\end{array}$ \\
\hline 12 & March 2013 & Brasilia & $\mathrm{FtF}$ & EU Delegation to Brazil \\
\hline 13 & March 2013 & Brasilia & $\mathrm{FtF}$ & University of Brasilia \\
\hline 14 & March 2013 & Brasilia & $\mathrm{FtF}$ & $\begin{array}{l}\text { Brazilian Ministry } \\
\text { of Mining \& Energy }\end{array}$ \\
\hline 15 & March 2013 & Piracicaba & $\mathrm{FtF}$ & $\begin{array}{l}\text { Sugarcane Research } \\
\text { Center (CTC) }\end{array}$ \\
\hline 16 & April 2013 & Brussels & $\mathrm{FtF}$ & UNICA \\
\hline 17 & September 2013 & & Telephone & DG Trade \\
\hline 18 & September 2013 & Brussels & $\mathrm{FtF}$ & $\begin{array}{l}\text { Brazilian Delegation to } \\
\text { the EU }\end{array}$ \\
\hline 19 & October 2013 & Brussels & $\mathrm{FtF}$ & DG Energy \\
\hline 20 & October 2013 & Brussels & $\mathrm{FtF}$ & UNICA \\
\hline 21 & October 2013 & & Telephone & $\begin{array}{l}\text { EU Delegation } \\
\text { to Mozambique }\end{array}$ \\
\hline 22 & October 2013 & & Telephone & $\begin{array}{l}\text { EU Delegation } \\
\text { to Kenya }\end{array}$ \\
\hline 23 & July 2014 & Dar es Salaam & $\mathrm{FtF}$ & $\begin{array}{l}\text { Embassy of Brazil to } \\
\text { Tanzania }\end{array}$ \\
\hline 24 & August 2014 & São Paulo & $\mathrm{FtF}$ & University of São Paulo \\
\hline 25 & August 2014 & São Paulo & $\mathrm{FtF}$ & FGV \\
\hline 26 & August 2014 & Rio de Janeiro & $\mathrm{FtF}$ & BNDES \\
\hline
\end{tabular}


Appendix (Continued)

\begin{tabular}{|c|c|c|c|c|}
\hline No. & Date & City & Mode & Actor \\
\hline 27 & September 2014 & Brasilia & $\mathrm{FtF}$ & $\begin{array}{l}\text { Brazilian Ministry of } \\
\text { Agriculture }\end{array}$ \\
\hline 28 & September 2014 & Brasilia & $\mathrm{FtF}$ & $\begin{array}{l}\text { Brazilian Ministry of } \\
\text { External Relations }\end{array}$ \\
\hline 29 & September 2014 & Brasilia & $\mathrm{FtF}$ & $\begin{array}{l}\text { Brazilian Ministry of } \\
\text { Mining \& Energy }\end{array}$ \\
\hline 30 & September 2014 & Brasilia & $\mathrm{FtF}$ & FGV \\
\hline 31 & September 2014 & Brasilia & $\mathrm{FtF}$ & EU Delegation to Brazil \\
\hline 32 & September 2014 & & Telephone & GranBio (Alagoas) \\
\hline 33 & September 2014 & Brasilia & $\mathrm{FtF}$ & US Embassy to Brazil \\
\hline 34 & May 2015 & Maputo & $\mathrm{FtF}$ & $\begin{array}{l}\text { Universidade } \\
\text { Eduardo Mondlane }\end{array}$ \\
\hline 35 & May 2015 & Maputo & $\mathrm{FtF}$ & $\begin{array}{l}\text { EU Delegation to } \\
\text { Mozambique }\end{array}$ \\
\hline 36 & June 2015 & Maputo & $\mathrm{FtF}$ & $\begin{array}{l}\text { Ministry of Agriculture/ } \\
\text { Food Security }\end{array}$ \\
\hline 37 & June 2015 & Maputo & $\mathrm{FtF}$ & Ministry of Energy \\
\hline 38 & June 2015 & Maputo & $\mathrm{FtF}$ & Sugar estate \\
\hline 39 & June 2015 & Maputo & $\mathrm{FtF}$ & Sugar mill \\
\hline 40 & June 2015 & Maputo & $\mathrm{FtF}$ & $\begin{array}{l}\text { Embassy of Brazil to } \\
\text { Mozambique }\end{array}$ \\
\hline 41 & June 2015 & & Telephone & $\begin{array}{l}\text { Energy } \\
\text { consultant }\end{array}$ \\
\hline 42 & June 2015 & Maputo & $\mathrm{FtF}$ & $\begin{array}{l}\text { Independent Energy } \\
\text { consultant }\end{array}$ \\
\hline 43 & September 2015 & São Paulo & $\mathrm{FtF}$ & UNICA \\
\hline 44 & September 2015 & São Paulo & $\mathrm{FtF}$ & Odebrecht \\
\hline 45 & September 2015 & Campinas & $\mathrm{FtF}$ & CTBE \\
\hline 46 & September 2015 & Brasilia & $\mathrm{FtF}$ & $\begin{array}{l}\text { Brazilian Ministry of } \\
\text { Agriculture }\end{array}$ \\
\hline 47 & September 2015 & Brasilia & $\mathrm{FtF}$ & $\begin{array}{l}\text { Brazilian Ministry of } \\
\text { External Relations }\end{array}$ \\
\hline 48 & September 2015 & Brasilia & $\mathrm{FtF}$ & $\begin{array}{l}\text { Brazilian Ministry of } \\
\text { Mining \& Energy }\end{array}$ \\
\hline 49 & September 2015 & Brasilia & $\mathrm{FtF}$ & UNICA \\
\hline 50 & September 2015 & Brasilia & $\mathrm{FtF}$ & $\begin{array}{l}\text { Brazilian Cooperation } \\
\text { Agency (ABC) }\end{array}$ \\
\hline 51 & September 2015 & Brasilia & $\mathrm{FtF}$ & US Embassy to Brazil \\
\hline
\end{tabular}


Appendix (Continued)

\begin{tabular}{lllll}
\hline No. & Date & City & Mode & Actor \\
\hline $\mathbf{5 2}$ & September 2015 & Brasilia & FtF & EU Delegation to Brazil \\
$\mathbf{5 3}$ & September 2015 & & Email & UNEP \\
$\mathbf{5 4}$ & October 2015 & & Telephone & Casa Civil \\
\hline
\end{tabular}

*Face-to-face. 